\title{
Reading from nowhere: assessed literary response, Practical Criticism and situated cultural literacy
}

Dr John Gordon, University of East Anglia

\begin{abstract}
School examinations of student responses to literature often present poetry blind or 'unseen', inviting decontextualised close reading consistent with the orientation-totext associated with Practical Criticism (originating in the UK) and New Criticism (originating in the USA). The approach survives in the UK after curricular reforms and government have promulgated cultural literacy as foundational for learning. How is cultural literacy manifest in student responses to literature? To what extent can it be reconciled with Practical Criticism where the place of background knowledge in literary reading is negligible? This article explores their uneasy relationship in pedagogy, curricula and assessment for literary study, discussing classroom interactions in England and Northern Ireland where senior students (aged 16-17) of English Literature consider Yeats' 'culture-making' poem 'Easter, 1916'. Using methods where teachers withhold contextual information as they elicit students' responses, the divergent responses of each class appear to arise from differing access to background knowledge according to local though superficially congruent British cultures. The author proposes 'situated cultural literacy' to advance the limited application of Practical Criticism in unseen tasks, acknowledge Richards' original intent, and support the coherence of assessment with curricular arrangements invoking cultural literacy as a unifying principle.
\end{abstract}




\section{Introduction}

A core academic literacy practice of native-language literary study requires instantaneous close reading of previously unseen texts, presented without contextualising detail. In class and examination students formulate responses and unearth what may seem like each poem's single secret message (Benton and Michael, 1995), their only resource the experiences they summon in immediate encounter with the page. Following a different trajectory UK government ministers, a revised National Curriculum for English (DfE, 2012) and various academy trust and free schools (Policy Exchange, 2015) advance ‘cultural literacy’ (Hirsch, Trefil \& Kett, 1988) as a foundational tenet across phases and disciplines. In English it is characterised by authorised lists itemising core texts (Clark, 1990) every student should know to access 'our precious intellectual heritage' (Gove, 2010). This article asks

i) how do students express cultural literacy in responses to unseen poetry offered spontaneously in class discussion? and

ii) what do their responses suggest about the appropriateness of unseen assessment within a discourse of cultural literacy?

Empirical transcript data from two lessons focussed on Yeats' 'Easter, 1916' (1920) suggest literary reading as dialogue between students' cultures (personal, regional, national) and what they divine of another voiced, represented or embodied in a text. Such reading is enhanced by cueing that situates orientation-to-text, through judicious intervention by teachers and with metatexts. Analysis critiques the disjunction between espoused curricular emphases and established modes of assessment: the two 
may be reconciled with improved coherence, fuller acknowledgment of their motivating theoretical influences and amended - situated - cultural literacy.

\section{Context}

Why does Cultural Literacy demand attention now?

Though the revised National Curriculum (DfE, 2012) predates the Brexit referendum it shares an impulse to redefine British nationhood. Narrowing criterion for 'heritage texts' (BBC News, 2012) in English mirror the United Kingdom's political repositioning relative to Europe, the United States and to itself, where identities across England, Northern Ireland, Scotland and Wales are ever more sharply delineated (Elliott, 2014).

Transatlantic synergies are revealed by a Schools Minister (Nick Gibb, DfE, 2016) invoking 'cultural literacy... the translinguistic knowledge on which linguistic knowledge depends' (Hirsch, Trefil, \& Kett, 1988:165). Hirsch believed the decline of American literacy standards and of commonly shared knowledge acquired in school were 'causally related facts', claiming that 'a certain extent of shared, canonical knowledge is inherently necessary to a literate democracy' (see also Core Knowledge UK, 2017). While Gibb champions a version of literacy combining 'specific contents as well as formal skills' and an English curriculum reorganised to furnish the requisite 'core cultural knowledge' of specific canonical works, he overlooks mismatched assessment formats inhibiting use of 'background knowledge' (Hirsch et al, 1988) in the explication of individual texts. The minister references Zadie Smith's novel NW (Smith, 2012) and wonders whether the protagonist might be 'irretrievably held back by her inability to distinguish between Oliver and Thomas 
Cromwell?' Gibb claims the extract to evidence his view 'that the recipient of a core academic curriculum leaves school with an intellectual hinterland, which allows them to make sense of the world around them'. The nature of his envisaged hinterland is clarified as he comments on the place of American literature in the English curriculum, specifically Of Mice and Men (Steinbeck, 1937):

Now, John Steinbeck is a great author - 'East of Eden' is my all-time favourite novel - but even I doubt this short novella was deserving of such overwhelming attention.

Gibb's own 'culture making' (Hirsch et al, 1988) also takes issue with Mark Twain's assertion that 'I've never let my school interfere with my education'. Twain's comment allows for education happening beyond schools, that the acquisition of knowledge, skills and understanding are not bound by institutional systems - and his writing is a vernacular articulation of the same. Clearly, there are different ways to define core cultural knowledge, and different means again to express it. For now the minister's definition holds sway, and isolationist policy making finds a mirror in an isolationist English Literature National Curriculum.

\section{Assessed literary response to 'unseen' texts}

The literary curriculum reframed nationhood just as revised assessment entirely through examination (Ofqual, 2015) abandoned coursework for the first time since the mid-1980s, consolidating the longstanding status of unseen close reading associated with Practical Criticism in the UK (Richards, 1929) and with New Criticism (Ransom, 1941) in the USA. The degree to which literary response is elaborated or narrowed by 
official frameworks is exposed in two illustrative examination papers. This question from England prompts this critical mode, inviting comment on Christina Rossetti's $A$ Birthday and Millay's Love is Not All:

It has been said that Rossetti's poem is conventional and celebratory, whereas Millay's poem offers a very different view of love. Compare and contrast the presentation of love in the following poems in the light of this comment.

It prompts response exploring the relationship between the two texts, assuming candidates encounter each for the first time. It neither invites exploration beyond these items nor encourages students to share their own cultural perspective. English examinations in literature use a nominalised abstraction called 'the presentation', often hiding the author entirely, ignoring circumstances of production, or oblivious to the world. In some, a rigid formula asks how a writer presents a character or theme, first in a decontextualized extract, then with reference to the whole (AQA, 2015). Though one assessment objective in current specifications invites students to 'explore the contexts of the texts they are reading and others' interpretations of them' (DfE, 2014), the close reading required of this particular question template is not aligned with cultural knowledge. It comes as a shock, then, to find this example from the Republic of Ireland (NCCA, 2010) where their connection is a central principle. It is so different it might derive from a different subject:

Many of Eavan Boland's poems observe our violent history in a vivid and moving way; in spite of this, she does not take sides except to mourn the hurt. Discuss. 
Criticism is a foreign country: they do things differently there. The open invitation encourages divergent response, while the candid summation of the nation's history is unthinkable in English public examination. It articulates a relationship between text and context to challenge the misconceived version of Practical Criticism found in English examinations, hotwiring candidates' responses to immediate, personal and shared experience.

\section{Theoretical framework}

\section{Practical Criticism}

The dominant conception of Practical Criticism is typified in that Rossetti/Millay question requiring 'the close reading of words on the page... a way of appreciating the power of literary language' (Day, 2008). Such activity 'involves the intense scrutiny of a piece of prose or poetry, concentrating on the words on the page and disregarding the work's context' (Eaglestone, 2008). This version of Practical Criticism where manifest in assessment and critical practice in schools distorts the intent of Richards' original investigations concerning literary response, 'isolating the text from history and context' (Barry, 1995). West (2002) tempers the influential view that Richards intended such reading as an ideal mode of literary pedagogy: 'Richards' procedure of issuing anonymous poems and asking for comments was explicitly part of an experiment, and was certainly not how he thought that we should or could read a literary text'. Instead, West emphasises Richards' awareness of 'the difficulty of judging verse without a hint as to its provenance' (Richards, 1929) and concludes that the misconception of Practical Criticism constitutes 'one of the major ironies of twentieth-century literary criticism'. Richards' exploratory intent was evident in this 
playful remark: 'the technique of the approach to poetry has not yet received half so much systematic study as the technique of jumping'. His was a serious study of 'the nature of interpretation... the process by which we as human beings make meaning from language'. While it had evident interest in response to decontextualised unseen texts, it was not intended as the blueprint for examinations in literary reading across the century to follow.

\section{Cultural literacy}

West attributes to Richards the questions 'what prevents us from making meaning? What obstacles are there to communication?' For E.D. Hirsch the answer would be a deficit of 'national cultural literacy' (Hirsch et al, 1988), intimately bound with reading and comprehension. The concept holds that sharing 'a national language' requires 'knowledge of a canon of ideas, texts and cultural allusions that underpin that language. This is the shared knowledge that enables people to form implicit bonds as they communicate. It enables the rapid formation of alliances and the understanding of shared values' (Create, 2017, p.62). Hirsch asserts its 'key implications for narrowing the competence gap between different demographic groups' and hence for social justice outcomes in education (Avis, 2016; Young and Lambert, 2014; Arshad, Wrigley and Pratt, 2012). Comprising 'a finite body of knowledge, words, themes and values' (p.63), it is subject matter that 'does need to be prescribed up to a point', a principle adopted in some schools (see The Traditional Teacher, 2016; Young and Lambert, 2012) though independent evaluation (See, Gorad and Saddiq, 2017) tempers claims made for the impact of Core Knowledge on primary-phase reading attainment. Its relationship to reading in the mode Practical Criticism in the secondary phase is suggested in Hirsch's belief 'that relevant, unspoken knowledge is required 
to understand what is spoken' (p.69), and to observations described in his work (Hirsch, Trefil \& Kett, 1988) where 'some groups of students were able to understand passages of text more easily than others, and that this systematic difference was due to lack of familiarity with the context' (See, Gorad \& Saddiq, 2017).

\section{Methods and methodology}

Design and rationale

The unit of analysis for this study is the English Literature lesson, two examples presented as instrumental case studies (Stake, 1995, p.3) formulated according to the nominated interest (Hamilton, 2011), the relationship between students' responses to literature and the theoretical touchstones of cultural literacy and Practical Criticism. The method shares with arts-based research an interest in 'aesthetic vision... a sensitivity to suggestion, to pattern, to that which is beneath the surface itself' (Barone and Eisner, 2012, p.37) central to the discipline, where the poem typifies any literary text's unique 'pedagogic invitation' (Segall, 2004) and concurrent potential when considered for use by a teacher - to activate generalisable judgements informed by pedagogic content knowledge (Shulman, 1987) constituting subject expertise in English. Orientation to the cases follows Morrell's call (2005, p.1) for critical educators to 'draw upon the everyday language and literacy practices of adolescents to make connections with academic literacies and to work toward empowered identity development and social transformation'. While studies contest the literary canon (Cherry-McDaniel \& Young, 2012) foregrounding tensions between individual teachers' stated goals and practice (Macaluso, 2016), this analysis interrogates the premise of decontextualized response in a format where the limits of comprehension without contextualising detail can be voiced and explored. This adheres to a view of 
discourses as ideas (Johnstone, 2008, p. 3) - here, theories of literary reading - to similarly challenge 'the discursive systems of the official, implied, and enacted English curriculum that have persisted for decades' (Macaluso, 2016).

In the year of the Rising's centenary I explored the bearing of contextual knowledge on students' responses to 'Easter, 1916' with Advanced-level Literature classes in England and Northern Ireland. The poem is often taught in each territory, where attitudes to the Rising and relationships with the Republic have been in flux, sometimes divergently, across the intervening century. Echoing the premise of unseen poetry assessment as Practical Criticism in Richards' model (1929), I asked participating teachers to devise and audio record stand-alone one hour lessons to develop students' responses as far as possible according to information stated in the text, giving scope for students to introduce knowledge spontaneously and judging when to introduce contextual information themselves. After lessons I favoured plain text transcription of recordings over methods focussed on smaller analytic units, such as spoken 'stanzas' (narrative analysis: Gee, 1991) or 'turns' (Conversation Analysis: Sacks, Schegloff \& Jefferson, 1978; Seedhouse, 2004). Interpretation takes an 'educational connoisseur' perspective (Eisner, 1979) in the domain of literary pedagogic content knowledge (Shulman, 1997), the relationship between students' comments and the study text considered according to the theories of response outlined, and relative to English teaching as a community of practice (Wenger, 1998) familiar with them, the assessment apparatus and its curricular frame.

\section{Choice of focal study text}


The highly specific historical and political allusions of 'Easter, 1916' make distinctive demands of readers' knowledge. My own experiences of it as reader and teacher suggested its differentiated challenge according to regional perspective. It is a seminal instance of Yeats' project to explore national identity, intriguing relative to cultural literacy and Hirsch's proposition that the 'implicit function' of the humanities is 'national culture-making' (Create, 2017). Moreover, as a senator of the nascent Irish Free State's government, Yeats argued against 'a narrow or solipsistic approach to national culture' (Foster, 2003, p.239). The poem describes the Irish Easter Rising, sometimes termed the Easter Rebellion. The Rising's instigators aimed to establish an Irish republic independent of British rule, but by April 1916 their efforts had failed and many of its leaders were executed. The poem's title signals details of the event as salient, though for me they were unfamiliar and not readily gleaned. Teaching in a school on the Norfolk-Suffolk border, some of these were as obscure to me - a Yorkshireman guiding an Advanced Level course in Literature - as they were to my seventeen-year old students. I could not claim direct familiarity with these events, having lived to a different set of cultural reference points. I had never been to Dublin.

The poem's second stanza, here without supporting contextual information, demonstrates some of the text's challenges:

That woman's days were spent

In ignorant good-will,

Her nights in argument

Until her voice grew shrill.

What voice more sweet than hers 
When, young and beautiful,

She rode to harriers?

This man had kept a school

And rode our wingèd horse;

This other his helper and friend

Was coming into his force;

He might have won fame in the end,

So sensitive his nature seemed,

So daring and sweet his thought.

This other man I had dreamed

A drunken, vainglorious lout.

He had done most bitter wrong

To some who are near my heart,

Yet I number him in the song;

$\mathrm{He}$, too, has resigned his part

In the casual comedy;

$\mathrm{He}$, too, has been changed in his turn,

Transformed utterly:

A terrible beauty is born.

It provokes questions defying easy deduction through close reading of these words or to the rest of the poem. Who is the woman? Why does the horse have wings? How many people are described here? All are questions I asked myself or heard asked by others, all are reasonable as readers seek purchase on information and quest for meaning. A close reading approach that believes sense can be deduced from a text in 
isolation falls short here even when building from the supposedly stable guide of syntax. Adopting purist close reading, I might work from the assumption that within this deictic list of protagonists Yeats uses the semi-colon with equal force on each occasion. From that I might deduce there are four actors referred to in addition to 'that woman', if the semi-colon serves as boundary marker between one and the next each time. The hypothesis finds traction in the poem's final stanza where four people are named. It turns out the final stanza works to a different though overlapping list: an Irish colleague tells me the 'helper and friend' and the 'sensitive' man are one, that in Ireland nobody could possibly sunder the two to summon a fourth imagined man. The Rising is a seminal political, cultural and social reference point, 'core cultural knowledge' in the vernacular and in the system.

\section{Fieldwork: orientations to teaching}

I shared with participating teachers these traits of 'Easter, 1916', generalisable to many other poems:
a) It has sections with strong narrative momentum;
b) Equally there are sections concentrated around symbols rather than narrative momentum;
c) It contains details allowing some explication of the historical moment;
d) It nevertheless requires some metatextual knowledge to be understood;
e) It has a voice which is self-conscious about the form it is using;
f) It recognises and uses aspects of forms beyond poetry.

(Gordon, 2014) 
As teachers decide an approach sympathetic to the text under immediate consideration, corresponding questions (also generalisable) activating pedagogical content knowledge and associated judgement might be:

a) How can I help students make sense of the narrative?

b) How can I help students attach meaning to the symbols used?

c) What can students draw from within the poem that provides information about the historical moment described?

d) What further texts will I select and use with students, and with what rationale?

e) What is the persona of the voice and its relationship with the text?

f) What are the features of the form, and to what extent is it familiar to students?

Of these, teachers concentrated on the third and fourth items (c and d) in each list.

\section{Data and commentary}

\section{Case one: close reading in England}

\section{i) Lesson context}

The teacher invites co-educational students to share their knowledge of the Irish rebellion: 'Does anybody know what the Easter Rising was?' Responses are tentative and enquiring: Was it a revolution against the government? Is it like the British government was trying to take a part of Ireland? Does it have anything to do with the 
First World War? Prompted to consider the poem's title ('what do you think the poem might be about?'), students develop discussion from first positing that it is about 'a big event during that time' to the speculation that it concerns 'rebirth, that kind of thing'. This progress marks a shift from a historical orientation (founded on available 'national cultural literacy') to more generalised attention to symbolism focused on Easter as a symbol for rebirth where Good Friday, crucifixion and the Resurrection are proposed as associated concepts

\section{ii) Critical episode}

This mode is sustained after the teacher plays a recording of the poem, the next contributor noticing the poem opens with 'references to being born and ends that way as well'. The same student hypothesises 'that although the uprising didn't work, there is still hope for the uprising'. The teacher wonders aloud about the 'thing that's being born, what the 'terrible beauty' represents'. The response demonstrates close reading in scrutiny of a single repeated noun phrase and use of analytic discourse:

We were just talking about the important oxymoron and the phrase 'terrible beauty' and the idea of 'birth'. It's not really something you couple with terrible, you are alluding to the idea of miracle of life and it being a beautiful thing. You don't really think it's terrible, so to have it in the same sentence is kind of weird.

The significance of the oxymoron is taken up. It could convey 'a sense of regret, a terrible beauty that's something beautiful but it's a dangerous thing'. He draws a parallel with 'roses'. The associative approach continues as the class moves to 
consensus about the text's mood as 'fairly bleak, fairly minimal', then transforming this observation into one about the poem's structure. They trace an intensification of bleakness from a 'really bitter and negative' attitude in the first stanza (that the conversation is 'polite' and 'meaningless') to stanzas three and four where Yeats introduces the symbol of the 'stone'. One student feels that 'everything seems like stones were heavy things, to make the poem feel weighted'. Another links this heaviness with 'the way that there are very few words per line, and they weren't very spaced out on the page'. He continues:

Instead of painting us a colourful, vivid image he's painted it very shallow almost. There are lot of gaps for you to fill in with your mind, and that creates a sense of emptiness and possibly bleakness.

Facility in summarising personal responses invoked by the poem is apparent again in this student's contribution, towards the end of the discussion:

by looking at each stanza individually you can see the build-up and the relationship between people, and unity. In the first stanza, even in the first line it's 'I' and not 'them' - a division and lack of relating to people. Then in the second stanza he is saying 'that woman' and 'this man', and you're identifying people in quite an ambiguous way. Then in the third stanza, taking the first line, 'Hearts with one purpose also', so there is a sense of people coming together with one aim. There's a sense of, yes, unity and then finally the fourth stanza. You can see that it takes over because they're referring to relationships 
like mother and child, and their dreams. It's a sense of coming together, which is very different too.

It suggests her own cognitive and affective process of making meaning, reflection representing traits of Practical Criticism, including assertion of textual coherence as a marker of literariness and value. This mode's dominance contrasts with the relative infrequency of contributions about the events, locations and personalities described in the poem, despite invitation to do so. Those would have suggested mutual awareness of the Easter Rising, manifesting shared 'core cultural capital' about the rebellion. When made, they are generalised. One student refers to Ireland in the twelfth century, to an unspecified battle with England. Elsewhere, attending to stanza two, students deduce that people mentioned have 'changed themselves for the revolution', including the 'vainglorious lout' who has been 'transformed', but there is no secure identification of any one figure. Asked how many people are described, the first offer is five. My Irish colleague would challenge this student just as he challenged me.

\section{Case two: activating cultural knowledge in Northern Ireland}

\section{i) Lesson context}

Students in this girls' school share readily accessible and embedded knowledge of the Rising as they analyse the poem, brought to bear on critical activity with an ease often unmediated and unprompted by the teacher. They attempt to name the figures described in stanza two, which their teacher had just read aloud. 


\section{ii) Critical episode}

Students introduce details not presented in the poem, doing so to support and develop a hypothesis about the anonymous female figure it describes and her significance:

Teacher: So we aim to get the kind of listing of the kind of people involved. Now you were saying you thought it was Maud Gonne?

Student: I th- think it's like, like an almost a metaphorical approach to like Ireland I (suppose)

Teacher: Right.

Student: On the whole kind of like a classic (mirror) image of Maud Gonne 'cos that's, was always (unclear) always had it in somewhere in any poem so I think like he's actually like personifying Ireland as a woman.

Teacher: That's very interesting because that was done at the time, yeah.

Student: Mm, a lot.

Teacher: Lots of her iconography, erm, if we - before I do tell you who I think this is, and there are links as well to the same classic Maud Gonne (unclear), what other things would give you clues in there as to who this is, does anybody know who this is?

Student: Is it Countess Markievicz?

Teacher: Yeah, it's Countess Markievicz. What do you know about her?

Student: Erm, I know that she was involved in the Easter Rising.

Teacher: Yeah -

Student: And then she was arrested

Teacher: Yeah. 
Student: And they wouldn't try her because she was a woman and that she was also involved in Daughters of Ireland.

Teacher: Good, yeah, and do you know how - how Yeats knew her?

Student: No, was she - was she not just from the same social circle of Belfast?

Teacher: She was, absolutely.

The teacher does not immediately challenge the incorrect hypothesis that the figure is Maud Gonne. It seems important that the student is permitted to propose and share information about a figure acquainted with Yeats (she was his unrequited love) and with the Irish nationalist movement. The knowledge that this student articulates and others apparently share has sufficient depth for them to have a sense of the figure's personality, which they apply to their analysis. As in the exchange presented in English data, this process builds from an interpretation of a detail understood in literal terms (this person is a woman), to hypothesis (it may be Maud Gonne), to a reading of it as signifying something greater, some abstracted quality. Here that shift is expressed in the proposal that Yeats is 'personifying Ireland as a woman'. The way the exchange develops suggests other participants accept the interpretation as reasonable, and points to shared cultural capital confirming the legitimacy of the hypothesis. For now the teacher endorses the proposal, taking the opportunity to signal Yeats' use of similar personification strategies elsewhere (he 'always had it somewhere in any poem'). In this respect the teacher's activity parallels the approach of the teacher in the lesson from England. The key variable contributing to differing response is the knowledge students bring to discussion which, after a steer from the teacher, also affords self-correction. As the teacher says '... before I do tell you who this is', one student offers the alternative hypothesis that the woman is instead 
'Countess Markievicz'. With further prompting the student contributes plentiful and impressively exact detail. 'Daughters of Ireland' was an organisation founded by Maud Gonne, of which Markievicz later become a member. The overlap confirms the earlier contribution about Maud Gonne as legitimate cultural capital: it is very obviously from the same sphere of knowledge, comprising awareness of the same actors in similar events. The student activates knowledge from beyond the text, derived from social, cultural and historical capital intersecting with that of her peers and the teacher even if they do not share exactly the same details. No other student seeks clarification about the organisation mentioned. The group tacitly recognises 'Daughters of Ireland', suggesting shared knowledge that we would not expect the students in England to demonstrate given their greater remove from the political history of Ireland.

\section{Discussion}

That students might ever offer decontextualised response to unseen texts is revealed as a highly problematic proposition. The second case illustrates how tacit cultural literacy facilitates response, activated as 'situated understanding... customizable to different specific situations of use' (Gee, 2003, p.26). It challenges the validity of unseen assessments of literary response given the variable entry points for candidates' reading. If these are clear around 'Easter, 1916' where the title cues teachers' planning to recognise knowledge capital's role, not all poems so directly signpost the need for contextualising support. Cultural difference of response may be obscured, the sophisticated energies at play left unrecognised. Further data show how teachers and students in each setting acknowledged these tensions, first in explicit discussion of 
them and second where the teacher's planned use of metatexts supports instantaneous response to resolve them.

\section{Students' perspectives on the limits of unseen response}

In England the teacher opened discussion of contextual information's value: 'How satisfying is this poem without knowing the information that you don't know?' Students' responses admit merit in limiting contextual detail, as if its absence affords initially attentive reading. A male student remarks:

it's fine not knowing the context first of all, because if you know the context you can't invent meanings in your head, that you wouldn't necessarily already know. Without the context you find new meanings.

Decontextualized close reading is a creative process promoting invention, limited insofar as 'with the context you can further develop those meanings'. Another student asserts a similar dynamic, corroborating the limiting absence that follows the initial 'mental exercise':

Afterwards, without the context, I feel like I'm missing too much because I've inferred from what I think it is, rather than what it actually is.

Echoing descriptions of an unhelpful literary pedagogy where criticism is construed as puzzling out (Benton \& Michael, 1995; Benton, 1986), she offers the understated evaluation 'it's not an easy read.' 
Reconciling Practical Criticism and background knowledge: eliciting and situating students' cultural literacy

In Northern Ireland, the teacher makes gentle use of visual texts (see figures 1 and 2) to assist students' exploration of the poem and consolidate understanding of Countess Markievicz's significance in stanza two. She builds personal anecdote around a photograph of Markievicz, bridging the political realm of the Rising with Markievizc's domestic life and concurrently weaving in her own vicarious experience of the combination:

Teacher: There she is when she's younger [shows photograph], when she was at Lissadell as a young woman. You can see the size of her waist, one of those Victorian tiny tiny waists and dressed as if for a ball, so she was very much part of that ascendancy kind of culture in Ireland. And these are some of the lines that he [Yeats] famously wrote about her: 'the light of evening, Lissadell great windows open to the south two girls in silk kimonos both beautiful one a gazelle' - and that was her, that was Constance. When I was a child, before Lissadell was closed and reopened, her aunts were still living there and you could go and you could talk to them about her. One time my husband visited and being mischievous he said - 'cos the aunts were awfully awfully old by then, they were very, erm, you know they were very ladylike and everything - he said, do you think Constance ever shot anybody?

Students: laughter

Teacher: And they went oh, no no no! Constance (unclear) things 


\section{Students: laughter}

Teacher: She didn't actually carry arms, whether she shot anybody or not... (unclear) and here she is, she's changed, changed utterly.

One student makes an aside about the power of images, not quite distinct in the recording, though the teacher responds clearly with affirmation: 'that's right - it's such a transformation into a uniform, you know, and she is commemorated beautifully in Sligo, the fantastic kind of statue to her. So this is the first name, this is the first person'. The exchange arrives back at the poem, informing and confirming close reading informed by cultural capital. Interplay of photograph and verbal comment in informal register highlights elements of Markievicz's biography key to developing understanding of the stanza. The way the teacher deploys the photograph situates Markievicz in place, time and class and makes her a greater presence in the reading of the poem. None of this is trivial. Students delight in the teacher's punning on the poem's refrain, 'changed, changed utterly'. The riff strikes beautifully to the heart of the matter, the bathetic re-assignment of the refrain to changing clothes recalling and underscoring the alteration of each protagonist described in this stanza. Each undergoes a transformation from relatively mundane existence first to rebel and then to martyr. The exchange concludes with the teacher's reference to a statue of Markievicz, in a comment perhaps drawing subtle parallel with the poem's detail of hearts 'enchanted to a stone'. The teacher has skilfully elicited students' knowledge to link poem, 'activity and experiences in the world' and 'knowledge as facts and information... situated as opposed to verbal understandings' (Gee, 2003, p.28). 


\section{Conclusion}

Each case demonstrates that cultural literacy manifest in students' responses to literature is not an easily quantifiable commodity: its extent and expression differs across classrooms, communities and countries. Study texts cannot be understood according to one prescribed package of decontextualized core knowledge. Means to activate students' existing and diffuse background knowledge are finely judged. Only with skilled guidance does response approach confident interpretation. Activation of this situated understanding 'has many implications for the nature of learning and teaching, as well as for the assessment of learning and teaching' (Gee, 2003, p.38). Unseen assessments that do not countenance background knowledge as a factor in response, or permit contextualizing detail in design, are ill-conceived and inconsistent with the discourse of cultural literacy that currently has influence. Balanced, valid assessments of literary reading must acknowledge cultural literacy's nuance, better supporting students to articulate responses informed by their distinctive background knowledge. Success in this entails re-evaluating I.A.Richards' pioneering readerresponse method which does not preclude considering literature relative to its provenance but confirms its importance. Data here show students need a scaffold, however gently provided. Like the Irish examination papers, revised assessment tools should provide prompts linked to current perspectives or set literary works alongside complementary metatexts (such as a published interview with the poet), so students can situate their position between texts rather than flounder in a void of guesswork. The confused relationship between curriculum, knowledge and assessment (Christodoulou, 2015) can be reset. 
A different way to assess responses to 'Easter, 1916' might attempt "what teachers can do and tests can't" (Ian Duhig quoted in The Telegraph, 2014), setting it alongside Duhig's own reformulation of 'a terrible beauty' in the poem 'Brilliant'. Written after the London bombings following 9/11, it relocates Dublin's social scene of 'polite meaningless words' to Leeds:

I sorted the world out with Sid -

agreeing when all's said and done,

we said a lot more than we did.

The deictic puzzle of Yeats's stanza two, with its confusing list of protagonists, is transformed in content and register:

This bomber's Dad ran a chip shop

which fried not with dripping but oil;

on match days he stood on the Kop

with Sid, now Sidique, from the school -

they wrote his work up in the TES.

You'd think you knew what Sid dreamed

he showed such social-consciousness,

so sensitive his nature seemed.

But drugs had this other young man,

till his parents sent him to learn

at a madrassa in Pakistan.

He too has changed in his turn. 
Duhig, an Irish-English poet himself, situates Yeats' poem anew for a different audience with different experiences and different reference points. Reading now, we synthesise Duhig's lines divergently according to 'millions of semi-independent impulses' (Richards, 1929) uniquely our own, though our proximity in time to the Manchester Arena suicide bombing of summer 2017 further complicates response relative to a redefined point of national reference. The timing of the comparison today sets it apart from the Rossetti/Millay pairing: with its echoes of Yeats' poem, 'Brilliant' compels a 'close attention to language and metaphor' and juxtaposed even triangulated with related news items? - both may become 'thrillingly available' (Create, 2017).

Invoking this situated cultural literacy reorients literary-critical reading, making subject-specialist response both to immediate frameworks and to the Organisation for Economic Co-operation and Development's 'case for 21st-century learning' (Schleicher, 2010) which asserts 'success is no longer about reproducing content knowledge, but about extrapolating from what we know and applying that knowledge to novel situations'. This ideologically (Street, 2003) self-aware and subtly situated academic literacy (Barton et al, 2000) can legitimately maintain close reading where it provokes 'ways of thinking which involve creative and critical approaches to problem-solving and decision-making' (Schleicher, 2010). Education for 'active and engaged' citizens in a 'multi-faceted world' additionally demands greater recognition of contexts of literary production and reception in curricular detail and assessment. Where cultural literacy is invoked, it must note Hirsch's anti-solipsistic distinction 'between community-oriented patriotism and militant nationalism' (Create, 2017). 
Students should interrogate English literary culture, its provenance, maintenance, boundaries and variation in time, and articulate their own experience in relation to it. Notably for the English canon, Schleicher rejects knowledge we find in 'an encyclopaedia'. Modern literacy entails managing 'non-linear information structures' and content free of disciplinary classification: 'knowledge advances by synthesizing these disparate bits'. Situated cultural literacy can nurture his 'versatilists' and value both their knowledge and 'precious intellectual heritage', generating 'powerful knowledge' rather than recycling 'knowledge of the powerful' (Young, 2008). It sustains Practical Criticism in more flexible mode, open to background knowledge and material locating focal texts. Curricularised literary response cannot continue without compass, reading from nowhere. 


\section{References}

AQA (2015) A-level English Literature A (7712/1) paper 1: Love through the ages. Manchester: AQA, 2015.

Arshad, R., Wrigley,T. \& Pratt, L. (eds) (2012). Social justice re-examined: Dilemmas and solutions for the classroom teacher. London: Trentham.

Avis, J. (2016) Social justice, transformation and knowledge: Policy, workplace learning and skills. London: Routledge.

Barone, T. and Eisner, W.E. (2012) Arts-based research. Los Angeles: Sage.

Barry, P. (1995) Beginning theory: an introduction to literary and cultural theory. Manchester: Manchester University Press.

Barton, D., Hamilton, M. \& Ivanic, R. (2000) Situated Literacies. London: Routledge.

BBC News (2012) Cultural literacy: Michael Gove's school of hard facts, www.bbc.co.uk/news/education-20041597 (accessed 20.3.17).

Benton, M. and Michael, B. (1995) 'The discipline of literary response: approaches to poetry with L2 students', 47, 333-342.

Benton, P. (1986) Pupil, teacher, poem. London : Hodder and Stoughton, 1986.

Cherry-McDaniel, M., and Young, A. F. (2012) 'Complicating the canon: disrupting what we know'. English Leadership Quarterly, 34(3), 8-11.

Christodoulou, D. (2015) 'Assessment knowledge' in Policy Exchange (2015) Knowledge and the Curriculum.

Clark,W. (1990) 'Literature, education, and cultural literacy', Journal of Aesthetic Education. 24(1), 49-56.

Core Knowledge UK (2017) E.D.Hirsch and cultural literacy, www.coreknowledge.org.uk/culturalliteracyck.php (accessed 20.3.17). 
Create (2017) How cultural literacy makes us all insiders: Create discusses language, culture and progress with E. D. Hirsch, Jr., www.artscouncil.org.uk/sites/default/files/downloadfile/Create\%20ED\%20Hirsch\%20Cultural\%20literacy.pdf (accessed 18.7.17).

Day, G. (2008) Literary criticism: A new history. Edinburgh : Edinburgh University Press, 2008.

DfE (2012) National curriculum in England: English programmes of study, www.gov.uk/government/publications/national-curriculum-in-englandenglish-programmes-of-study (accessed 20.3.17).

DfE (2014) GCE AS and A level subject content for English literature, www.gov.uk/government/publications/gce-as-and-a-level-for-englishliterature (accessed 20.3.17)

DfE (2016) Nick Gibb: what is a good education in the 21st century? www.gov.uk/government/speeches/what-is-a-good-education-in-the21st-century (accessed 20.3.17).

Duhig, I. (2007) 'Brilliant', The speed of dark. London: Picador.

Eaglestone, R. (2008) Doing English : A guide for literature students. Abingdon : Routledge, 2002. $2^{\text {nd }}$ ed.

Eisner, W.E. (1979) The educational imagination. New York: Macmillan.

Elliott, V. (2014) 'The treasure house of a nation? Literary heritage, curriculum and devolution in Scotland and England in the twenty-first century', The Curriculum Journal, 25(2), 282-300.

Foster, R.F. (2003) W.B.Yeats - a life: II The arch poet. New York: OUP

Gee, J.P. (1991) 'A linguistic approach to narrative', Journal of Narrative and Life History. 1(1), $15-39$. 
Gee, J.P. (2010) 'A situated sociocultural approach to literacy and technology' in Baker, E. A. (ed) (2010) The new literacies: Multiple perspectives on research and practice. New York: Guilford Publications.

Gordon, J. (2014) A pedagogy of poetry through the poems of W.B. Yeats. Stoke-onTrent : Institute of Education Press, 2014.

Gove, M. (2010) All pupils will learn our island story, http://conservativespeeches.sayit.mysociety.org/speech/60144 (accessed 17.7.17)

Hamilton, L. (2011) Case studies in educational research. British Educational Research Association.

Hirsch, E. D. (1990) 'Reflections on Cultural Literacy and Arts Education', Journal of Aesthetic Education. 24 (1), 1-6.

Hirsch, E. D., Trefil, J., \& Kett, J. F. (1988) Cultural literacy : What every American needs to know. New York: Vintage Books.

Macaluso, M. (2016) 'Reading pedagogy-as-text: Exploring gendered discourses as canonical in an English classroom', Linguistics and Education, 35, 15-25.

Morrell, E. (2005). 'Critical English education', English Education, 37(4), 312-321.

NCCA (2010) Curriculum and assessment, www.ncca.ieen/Curriculum_and_Assessment/ (accessed 20.3.17).

OFQUAL (2015) GCSE changes: a summary, www.gov.uk/government/publications/gcse-changes-asummary/summary-of-changes-to-gcses-from-2015 (accessed 17.7.17)

Policy Exchange (2015) Knowledge and the Curriculum: collection of essays to accompany E. D. Hirsch's lecture at Policy Exchange, https://policyexchange.org.uk/wp- content/uploads/2016/09/knowledge-andthe-curriculum.pdf (accessed 17.7.17) 
Ransom, J.C. (1941) The New Criticism. Norfolk, Connecticut: New Directions.

Richards, I.A. (1929) Practical Criticism: a study of literary judgement. London: Routledge, Kegan and Paul.

Sacks, H., Schegloff. E.A. \& Jefferson, G. (1978) 'A simplest systematics for the organization of turn-taking for conversation' in Schenkein, J. (ed) (1978) Studies in the organization of conversational interaction (2nd ed). New York: Academic Press.

Schleicher, A. (2010) The case for twenty first century learning, www.oecd.org/general/thecasefor21st-centurylearning.htm (accessed 29.7.17).

See, B. H., Gorard, S. \& Siddiqui, N. (2017) 'Can explicit teaching of knowledge improve reading attainment? An evaluation of the Core Knowledge curriculum', British Education Research Journal. 43, 372-393.

Seedhouse, P. (2004) The interactional architecture of the language classroom: A Conversation Analysis perspective. Oxford: Blackwell Publishing.

Segall, A. (2004) 'Revisiting pedagogical content knowledge: the pedagogy of content/the content of pedagogy', Teaching and Teacher Education. 20(5), 489-504.

Shulman, L.S. (1987) Knowledge and teaching: Foundations of the new reform, in J. Leach \& B. Moon (eds) (1987) Learners and pedagogy. Milton Keynes: Open University Press.

Smith, Z. (2012) NW. London, New York : Hamish Hamilton.

Stake, R. (1995) The art of case study research. London: Sage.

Steinbeck, J. (1937) Of Mice and Men. New York : The Modern Library. 
Street B. (2003) 'What's "new" in New Literacy Studies? Critical approaches to literacy in theory and practice', Current Issues in Comparative Education, 5(2), $77-91$.

The Telegraph (2014) 'Primary school headteacher's inspirational letter to pupils goes viral', www.telegraph.co.uk/education/educationnews/10969735/ Primary-school-headteachers-inspirational-letter-to-pupils-goes-viral.html (accessed 20.3.17).

The Traditional Teacher (2016) The emptiness of the English curriculum, https://thetraditionalteacher.wordpress.com/2016/04/20/the-emptiness-of-theenglish-curriculum/ (accessed 20.3.17).

West, D. W. (2002) 'Practical Criticism: I.A. Richards' experiment in interpretation', Changing English: Studies in Reading \& Culture, 9(2), 207-213.

Wenger, E. (1998) Communities of practice: Learning, meaning, and identity. Cambridge: Cambridge University Press.

Yeats, W.B. (1920) 'Easter, 1916', Michael Robartes and the Dancer. Dundrum: Cuala Press.

Young, L. and Lambert, D. (2014) Knowledge and the future school: Curriculum and social justice. London: Bloomsbury Academic.

Young, M.F.D. (2008) Bringing Knowledge back in: From social constructivism to social realism in the sociology of education. London: Routledge. 